\title{
Analisis Kebijakan Penarikan Zakat Umar bin Khattab dan Relevansinya Terhadap Masa Krisis Pandemi Covid-19*
}

\author{
Azwar Iskandar ${ }^{1}$, Khaerul Aqbar ${ }^{2}$ \\ Sekolah Tinggi Ilmu Islam dan Bahasa Arab (STIBA), Makassar \\ do) \\ $10.15408 /$ sjsbs.v7i10.15359
}

\begin{abstract}
This research aims to analyze the policy of zakah gathering of Umar bin Khattab and to relevance it with the condition or crisis period of Covid-19 pandemic in Indonesia. This research uses qualitative method of descriptive approach with content analysis techniques and library research. The results showed several things. Firstly, among the policy forms of Umar ibn Khattab in zakah gathering are: (1) Umar bin Khattab allowed to take the badal (substitute) from zakah as an element of ease (taisir) for the Muzaki; (2) Umar bin Khattab is very flexible in taking zakat from Muslims, especially in certain conditions and situations. Secondly, the various policies of Umar ibn Khattab have strong relevance to the current Covid-19 pandemic crisis, so that it can be a reference to establishing a zakah policy in Indonesia.
\end{abstract}

Keywords: zakah, policy, collect, Umar, Covid-19

\begin{abstract}
Abstrak
Penelitian ini bertujuan untuk menganalisis kebijakan penarikan zakat Umar bin Khattab dan merelevansikannya dengan kondisi atau masa krisis pandemi Covid-19 di Indonesia. Penelitian ini menggunakan metode pendekatan kualitatif deskriptif dengan teknik content analysis (analisis isi) dan riset kepustakaan (library research). Hasil penelitian menunjukkan beberapa hal. Pertama, di antara bentuk kebijakan Umar bin Khattab dalam penghimpunan atau penarikan zakat adalah: (1) Umar bin Khattab membolehkan mengambil badal (pengganti) dari zakat sebagai unsur kemudahan (taisir) bagi para muzaki; (2) Umar bin Khattab sangat fleksibel dalam mengambil zakat dari kaum muslimin, khususnya pada kondisi dan situasi tertentu. Kedua, berbagai kebijakan Umar bin Khattab tersebut memiliki relevansi yang kuat dengan kondisi krisis pandemi Covid-19 saat ini, sehingga dapat menjadi rujukan dalam menetapkan kebijakan perzakatan di Indonesia.
\end{abstract}

Kata Kunci: zakat, kebijakan, penarikan, Umar, Covid-19

${ }^{*}$ Received: June 13, 2020, Revision: July 28, 2020, Published: October 14, 2020.

1 Azwar Iskandar adalah Staf pada Pusat Penelitian dan Pengabdian Masyararakat (P3M), Sekolah Tinggi Ilmu Islam dan Bahasa Arab (STIBA) Makassar. Email: azwar@stiba.ac.id.

${ }^{2}$ Khaerul Aqbar adalah Dosen sekaligus Kepala Pusat Penelitian dan Pengabdian Masyararakat (P3M), Sekolah Tinggi Ilmu Islam dan Bahasa Arab (STIBA) Makassar. Email: khaerul@stiba.ac.id. 


\section{A. PENDAHULUAN}

World Health Organisation (WHO) atau Organisasi Kesehatan Dunia mengumumkan status pandemi global pada tanggal 11 Maret 2020 karena wabah virus Covid-19 telah menyebar ke lebih dari 180 negara/kawasan di dunia. Beberapa lembaga riset kredibel dunia memprediksi dampak buruk penyebaran wabah ini terhadap perekonomian globa. ${ }^{3}$ Untuk Indonesia, Menteri Keuangan Republik Indonesia, Sri Mulyani Indrawati, memprediksi pertumbuhan ekonomi dalam skenario terburuk mencapai minus 0,4. ${ }^{4}$ Bahkan menurut Bank Dunia (2020), dampak ekonomi dari Covid-19 ini akan menyebabkan kemiskinan ekstrim hingga 922 juta di seluruh dunia. Di antara bentuk upaya yang diserukan dan dilakukan oleh dunia dalam rangka mengurangi penyebaran wabah ini adalah dengan social atau physical distancing. Namun sayangnya, gerakan ini membawa pengaruh pada penurunan aktivitas ekonomi secara keseluruhan. Proses penurunan perekonomian berantai yang ditimbulkan oleh Covid-19 ini tidak hanya menimbukan guncangan pada fundamental ekonomi riil, tetapi juga merusak kelancaran mekanisme pasar. Aspek-aspek vital ekonomi seperti supply, demand dan supply-chain menjadi terganggu, sehingga dampak krisis akan dirasakan secara merata ke seluruh lapisan atau tingkatan masyarakat utamanya pada golongan menengah ke bawah khususnya mikro dan informal dengan pendapatan harian.

Dengan kondisi seperti ini, sebagai negara dengan populasi muslim terbesar di dunia, umat Islam Indonesia pada dasarnya dapat memberikan peran terbaiknya melalui salah satu bentuk atau model filantropi dalam ekonomi dan keuangan Syariah yaitu zakat. Perintah untuk berzakat ini dapat berimplikasi tidak hanya terhadap peningkatan iman kepada Allah, tetapi juga dapat mengatasi berbagai masalah dalam kehidupan sosial, ekonomi, pendidikan, lingkungan dan aspek kehidupan lainnya. ${ }^{5}$ Oleh karenanya, dengan pengoptimalan semua potensi masyarakat, zakat akan menjadi sumber dana yang sangat potensial dan menjadi instrumen yang sangat penting dalam pemberdayaan ekonomi umat, pengentasan kemiskinan, dan mengurangi kesenjangan sosial. ${ }^{6}$ Lebih lanjut, zakat dapat meningkatkan produksi, memajukan investasi, meluaskan lapangan kerja, pengurangan kesenjangan sosial, pertumbuhan ekonomi yang semakin baik. ${ }^{7}$

Pada masa Nabi Muhammad saw., kewajiban mengeluarkan zakat dari golongan yang mampu (kaya) dikontrol langsung oleh Nabi saw. sehingga praktik

${ }^{3}$ Baldwin, R., Mauro, B. W. D. (2020). Economics in the Time of Covid-19. New E-Book. The Graduate Institute Geneva (April 2020): p. 1-10.

4 Azwar. Solusi Ekonomi dan Keuangan Islam di Masa Pandemi Covid-19. https://www.kemenkeu.go.id/publikasi/artikel-dan-opini/solusi-ekonomi-dan-keuangan-islam-saat-pande mi-covid-19/. Diakses pada tanggal 4 Mei 2020.

${ }^{5}$ Kasdi, A. (2016). Filantropi Islam Untuk Pemberdayaan Ekonomi Umat (Model Pemberdayaan ZISWAF di BMT Se-Kabupaten Demak). Iqtishadia: Jurnal Kajian Ekonomi dan Bisnis Islam, Vol. 9, No. 2. h. 227-245.

${ }^{6}$ Pratama, YC. (2015). Peran Zakat dalam Penanggulangan Kemiskinan (Studi Kasus: Program Zakat Produktif Pada Badan Amil Zakat Nasional). The Journal of Tauhidinomics, Vol. 1, No. 1 (2015): 93-104.

7 Marthon, S.S. (2007). Ekonomi Islam di Tengah Krisis Ekonomi Global. Jakarta: Zikrul Hakim. h. 126-128. 
zakat dapat berjalan dengan baik. Praktik seperti itu mengalami pergeseran ketika Nabi Muhammad saw. telah wafat. Wafatnya Nabi saw. dianggap oleh sebagian umat Islam yang murtad sebagai akhir dari pelaksanaan zakat, sehingga banyak yang tidak mau menunaikannya.

Pada masa khalifah Abu Bakr al-Shiddiq, setelah Rasulullah saw. wafat, orang-orang yang tidak mau menunaikan zakat diperangi. Banyak peperangan yang dilakukan Abu Bakr terhadap orang-orang murtad dan munafik yang tidak mau membayar zakat. Berbeda dengan Abu Bakr, pada masa kepemimpinan Umar bin Khattab, zakat dikelola dengan manajemen yang lebih baik. Umar bin Khattab banyak memberikan fatwa terkait zakat, ${ }^{8}$ dan melahirkan solusi-solusi yang cemerlang. ${ }^{9}$

Dalam konteks zakat, Umar bin Khattab menuangkan beberapa kebijakan baru yang belum pernah ditetapkan oleh khalifah sebelumnya. Kebijakan-kebijakan ini merupakan hasil dari pemahaman beliau terhadap nas al-Qur'an dan Sunah, bukan merupakan pemikiran yang tidak memiliki landasan di dalam syariat. Sebagai contoh, khususnya dalam konteks krisis, Umar menerapkan kebijakan yang sangat fleksibel dalam penarikan zakat. Umar bin Khattab mengundur pemungutan zakat dari para muzaki disebabkan oleh faktor tertentu, seperti yang terjadi pada tahun paceklik atau yang disebut dengan tahun ramadah. Kondisi krisis di masa itu berdampak besar pada pemerintahan, perekonomian, sosial, dan kesehatan.

Berangkat dari uraian di atas, menarik untuk melihat lebih jauh bagaimana kebijakan penarikan zakat yang dilakukan oleh Umar bin Khattab dan merelevansikannya dengan masa krisis Covid-19 saat ini. Beberapa penelitian terdahulu, seperti Munif, ${ }^{10}$ Maniroh, ${ }^{11}$ dan Aflaha, ${ }^{12}$ telah mengkaji bagaimana kebijakan-kebijakan yang telah diambil oleh Umar bin Khattab dalam penarikan zakat di masa pemerintahnnya. Namun demikian, penelitian-penelitian tersebut tidak merelevansikannya pada konteks krisis.

Adapun yang akan dibahas dalam penelitian ini adalah bagaimana regulasi dan kebijakan Umar bin Khattab dalam penarikan zakat. Pendapat dan kebijakan tersebut akan dibahas, dianalisis dan direlevansikan dengan kondisi krisis pandemi Covid-19 saat ini. Oleh karena itu, penelitian ini dilakukan dengan tujuan untuk menganalisis kebijakan penarikan zakat Umar bin Khattab dan merelevansikannya dengan kondisi atau masa krisis Pandemi Covid-19 di Indonesia. Rumusan permasalahan yang akan dijawab dalam penelitian ini adalah: (1) bagaimana kebijakan penarikan zakat Umar

8 Al-Andalusi, Ali bin Ahmad bin Hazm. (1404). Al-Ihkam fi Usul al-Ahkam. Qahirah: Dar al-Hadis. h. 87 .

9 Haikal, M. H. (1963). Al-Faruq Umar. Qahirah: Maktabah al-Nahdhah al-Mishriyyah, Vol. 1, h. 1.

${ }_{10}$ Munif, A. (2012). Analisis Pendapat Khalifah Umar Bin Khattab tentang Penundaan Penarikan Zakat Binatang Ternak Kambing yang Telah Mencapai Nisab. Muqtasid: Jurnal Ekonomi dan Perbankan Syariah, 3(2), 205-230.

${ }_{11}$ Maniroh, M. (2018). Penyelesaian Krisis Ekonomi menurut Umar bin Khatab" (Analisis terhadap Penundaan Pemungutan Zakat Hewan Ternak). Skripsi: STAIN Tengku Dirundeng Meulaboh.

12 Aflaha, A. N. (2019). Manajemen Krisis Ramadah Umar Bin Khattab Perspektif Sejarah Ekonomi Islam. Jurnal Rihlah, Vol. 7, No. 1. 
bin Khattab pada kondisi krisis di zamannya? (2) bagaimana relevansi kebijakan penarikan zakat Umar bin Khattab terhadap konteks krisis pendemi saat ini?

\section{B. METODE PENELITIAN}

Penelitian ini menggunakan metode pendekatan kualitatif deskriptif merupakan upaya memahami berbagai konsep yang ditemukan dalam proses penelitian, dengan menggunakan teknik content analysis (analisis isi) dan riset kepustakaan (library research). Teknik content analysis merupakan metode penelitian yang digunakan untuk mengetahui simpulan dari sebuah teks. Atau dengan kata lain, analisis isi merupakan metode penelitian yang ingin mengungkap gagasan penulis yang termanifestasi maupun yang laten. Sedangkan riset kepustakaan (library research) pada penelitian ini menggunakan jenis dan sumber data sekunder yang diperoleh dari hasil penelitian, artikel dan buku-buku referensi yang membahas topik yang berkaitan dengan tema penelitian. ${ }^{13}$

\section{ANALISIS DAN PEMBAHASAN}

Di dalam beberapa atsar, diriwayatkan bahwa Umar bin Khattab memiliki beberapa pendapat yang populer di dalam masalah zakat. Pandangan Umar bin Khattab ini tentunya merupakan pemahaman beliau terhadap hukum yang digali dari ayat-ayat al-Qur'an dan hadis-hadis Nabi saw. Di dalam pembahasan ini, kebijakan Umar dalam masalah penarikan zakat diklasifikasikan menjadi dua bagian. Pertama, kebijakan penarikan dan pengumpulan zakat. Kedua, relevansi kebijakan Umar tersebut dalam perzakatan di masa krisis pandemi Covid-19.

\section{Kebijakan Umar bin Khattab dalam Penarikan dan Penghimpunan Zakat}

Perintah zakat didasari atas dalil-dalil yang qath'i di dalam al-Qur'an. Allah swt. memberikan perintah yang tegas kepada orang-orang yang beriman, yang memiliki harta untuk mengeluarkan sebagian dari harta tersebut untuk disalurkan kepada golongan yang berhak menerima zakat. ${ }^{14}$ Namun demikian, Allah swt. tidak menjelaskan di dalam al-Qur' an, nisab (batasan minimal) harta yang wajib dikeluarkan zakatnya dan tidak pula dirincikan kadar zakat yang harus dikeluarkan. Kadar zakat dan batasan minimal harta yang dikeluarkan zakatnya diatur dan dijelaskan di dalam hadis-hadis Rasulullah saw. ${ }^{15}$ Oleh sebab itu, dalam kepemimpinannya, Umar bin Khattab kerap mengeluarkan kebijakan-kebijakannya secara luwes dan fleksibel.

${ }^{13}$ Azwar Iskandar dan Khaerul Aqbar, “Kedudukan Ilmu Ekonomi Islam di Antara Ilmu Ekonomi dan Fikih Muamalah: Analisis Problematika Epistemologis”, Nukhbatul 'Ulum: Jurnal Bidang Kajian Islam, Vol. 5, No. 2 (2019), h. 88-105.

${ }^{14}$ Lihat QS al-Nur/24: 56 dan QS al-Taubah/9: 10.

${ }^{15}$ Dalam beberapa hadis Rasulullah dijelaskan terkait kadar zakat dan batas minimal harta, di antaranya (artinya): “Apabila anda memiliki dua ratus dirham dan telah berlalu satu tahun, maka wajib zakat atasnya sebesar lima dirham. Anda tidak berkewajiban mengeluarkan zakat dari harta (emas) hingga 


\section{Prinsip Taisir (Kemudahan) oleh Umar dalam Jenis Harta Zakat yang Dikeluarkan}

Syariat yang Allah swt. turunkan kepada segenap manusia tidaklah bertujuan untuk memberatkan manusia. Allah selalu menghendaki keringanan dari setiap ibadah yang dilakukan oleh seorang hamba. ${ }^{16}$ Demikian juga di dalam konteks zakat, Umar bin Khattab menerapkan prinsip taisir (memberi kemudahan) kepada para muzaki yang hendak mengeluarkan zakat hartanya. Dengan prinsip taisir ini, beliau membolehkan mengeluarkan pengganti dari harta yang harus dikeluarkan sebagai zakat.

Pada dasarnya, zakat yang dikeluarkan atau diserahkan kepada amil adalah jenis harta yang menjadi objek zakat, misalkan emas, maka zakatnya adalah emas, zakat perak juga semestinya perak juga. Akan tetapi, Umar membolehkan mengambil badal (pengganti) yang memiliki nilai yang sama dari zakat tersebut sebagai unsur kemudahan bagi para muzaki. Disebutkan di dalam beberapa riwayat bahwa Umar bin Khattab mengambil barang dagangan sebagai pengganti dari zakat perak dan lainnya. ${ }^{17}$

Zakat merupakan suatu kewajiban yang harus ditunaikan oleh seorang muslim jika memiliki harta yang telah masuk ketentuan wajib dizakati tanpa ada perbedaan di antara para ulama sejak masa Sahabat Nabi saw. Menurut Qal'ahji, berdasarkan cara penyalurannya dari muzaki kepada mustahik, harta zakat yang ditunaikan oleh kaum muslimin, diklasifikasikan menjadi dua kategori. Pertama, amwal bathinah, yaitu harta yang terdiri dari emas, perak dan sejenisnya. Harta sejenis ini diberikan keleluasaan kepada muzaki untuk menyalurkannya secara langsung kepada mustahik. Di dalam satu riwayat dari Abu Sa'id al-Maqbari, ia berkata, "Suatu hari aku mendatangi Umar bin Khattab dan aku katakan kepadanya, "Wahai amirul mu'minin, ini adalah zakat hartaku", saat itu aku membawa dua ratus dirham. Maka beliau pun bertanya, "Apakah engkau sudah merdeka wahai Kaisan?" (Saat itu Abu Sa'id adalah seorang mukatab). ${ }^{18}$ Maka aku jawab, “Iya, aku sudah merdeka." Beliau pun melanjutkan, "Maka pergilah dengan zakat itu, dan bagikanlah langsung olehmu."19

Kedua, amwal zhahirah, yaitu harta yang terdiri dari barang dagangan, peternakan, pertanian, madu dan sejenisnya. Zakat dari jenis harta seperti ini ditarik oleh negara. Al-Kasani berpendapat di dalam Badai' al-Shanai' bahwa hak pengambilan zakat dari harta perdagangan adalah kepada pemerintah. Dan Rasulullah saw. dahulu

ia mencapai dua puluh dinar dan telah berlalu satu tahun, zakatnya adalah setengah dinar. Dan jika lebih, maka hitunglah berdasarkan kelebihannya." (HR Abu Daud, As-Sunan no. 1575). "Tanaman yang diairi air hujan atau sungai wajib dikeluarkan zakatnya sepersepuluh, dan yang diairi dengan disirami, maka zakatnya separuh dari sepersepuluh atau lima persen." (HR al-Bukhari, Shahih al-Bukhari no. 1403). “Tidaklah pada hasil tanaman (pertanian) yang kurang dari lima ausaq ada kewajiban sedekah (zakat). Tidak pula pada unta yang kurang dari lima ekor, ada zakat. Dan tidak pula pada perak yang kurang dari lima awaq, ada kewajiban zakat." (HR al-Bukhari, Shahih al-Bukhari no. 1484).

${ }^{16}$ Lihat QS al-Baqarah/2: 185 dan QS al-Hajj/22: 78.

${ }^{17}$ Lihat, Abu Bakr bin Abi Syaibah, Mushannaf Ibnu Abi Syaibah, (Cet. III; Dar as-Salafiyah, tt.), h. 181.

${ }^{18}$ Mukatab adalah seorang hamba sahaya yang membeli dirinya sendiri dari tuannya dengan bayaran yang ditunda dua kali atau lebih. Lihat, Muhammad bin Shalih al-Utsaimin, Al-Syarhul Mumti' 'Ala Dzad al-Mustaqni', (Cet. XIII; Cairo: Dar Ibnul Jauzi, 1428), h. 156.

${ }^{19}$ Atsar Riwayat Al-Baihaqi, As-Sunan Al-Kubra no. 7626. Abu Ubaid, Al-Amwal no. 1807, Ibnu Zanjawaih, Al-Amwal no. 2148. 
juga mengambilnya secara langsung, begitu pula Abu Bakar, Umar bin Khattab hingga masa Usman bin Affan. Akan tetapi ketika jenis harta perdagangan ini semakin beragam pada zamannya dan Umar pun memahami bahwa melakukan monitoring yang ketat akan menambah mudarat bagi para muzaki itu sendiri, maka beliau memandang bahwa merupakan maslahat jika penyaluran zakat dilakukan langsung oleh para muzaki. Maka mereka (pemilik harta) menjadi wakil dari pemerintah. Ketika Umar mengangkat para penakar zakat, beliau memerintahkan kepada mereka untuk mengambil zakat dari setiap pedagang muslim yang lewat sebanyak lima dirham dari dua ratus dirham. Ini menjadi zakat harta perdagangan mereka. Dan ketika para pedagang itu mengadu kepada Umar tentang ketatnya penghitungan yang dilakukan oleh pegawainya terhadap harta mereka, Umar pun memerintahkan kepada para penakar tersebut untuk berlaku ringan dalam menakar. ${ }^{20}$

\section{Fleksibelitas Waktu Penarikan Harta Zakat oleh Umar}

Salah satu dari syarat wajibnya suatu harta dikeluarkan zakatnya adalah terpenuhinya masa satu tahun dari kepemilikan harta tersebut atau yang diistilahkan dengan haul. Perhitungan satu tahun ini berlaku bagi semua jenis objek zakat kecuali zakat pertanian dan barang temuan (barang tambang dan rikaz). ${ }^{21}$ Seorang muzaki baru akan mengeluarkan zakat hartanya jika harta yang ia miliki sudah berada dalam kepemilikannya selama satu tahun. Oleh sebab itulah Umar tidak mengambil zakat dari pemberian yang diberikan orang lain karena belum berlalu waktu satu tahun.22 Namun demikian, di dalam beberapa riwayat didapatkan bahwa Umar bin Khattab sangat fleksibel dalam mengambil zakat dari kaum muslimin. Pada kondisi dan situasi tertentu, seperti pada krisis ramadah, Umar mengeluarkan kebijakan yang sangat fleksibel terkait hal ini. ${ }^{23}$

Krisis ramadah merupakan krisis yang pernah terjadi pada satu tahun di masa pemerintahan Umar bin Khattab. Krisis ini terjadi di seluruh wilayah Hijaz. Para pakar memperkirakan krisis ini terjadi antara tahun akhir $17 \mathrm{H}$ sampai awal $18 \mathrm{H}^{24}$. Situasi krisis pada masa itu digambarkan dengan kondisi di mana tanah berwarna hitam dikarenakan tidak turunnya hujan, hewan-hewan ternak mati dan manusia banyak terjangkit penyakit pada masa itu. Wabah pes penyakit menular) muncul di negeri Syam yang menyebabkan banyak orang meninggal sehingga perdagangan yang melalui negeri Syam terhenti. Pada saat terjadi krisi ramadah, manusia mengalami kelaparan berat disebabkan kemarau panjang dan paceklik ${ }^{25}$. Keadaan ini berdampak

${ }^{20}$ Muhammad Rawwas Qal'ahji, Mausu'ah Fiqh Umar, (Beirut: Dar al-Falah, 1981), h. 363.

${ }^{21}$ Rasulullah bersabda (artinya): "Dan tidak ada zakat pada harta sampai berlalu waktu satu tahun." (HR Ahmad, Al-Musnad no. 1264. HR Ibnu Majah, As-Sunan no. 1792, HR At-Tirmidzi, As-Sunan no. 631.

${ }^{22}$ Muhammad Rawwas Qal'ahji, Mausu'ah Figh Umar, h. 354.

${ }^{23}$ Aqbar, K., \& Iskandar, A. (2019). Kontekstualisasi Ekonomi Zakat dalam Mengentaskan Kemiskinan: Studi Kebijakan Zakat Umar bin Khattab dan Perzakatan di Indonesia. Laa Maisyir: Jurnal Ekonomi Islam, 6(2), 226-245.

${ }^{24}$ Al-Haritsi, Jaribah ibn Ahmad. (2015). Fikih Ekonomi Umar bin Khattab. Jakarta: Pustaka al-Kautsar. Ar-Risalah.

${ }^{25}$ Al-Thabari, Ibnu Jarir. (2000) Jami' al-Bayan fi Tafsir Ayi al-Qur'an. Cet. XIV; Beirut: Muassasah 
besar pada pemerintahan, perekonomian, sosial, dan kesehatan. Dalam menghadapi dampak krisis tersebut, Umar kemudian menerapkan beberapa kebijakan di bidang ekonomi, yaitu:

Pertama, Umar mengambil kebijakan untuk menunda pengambilan zakat binatang ternak karena banyaknya hewan yang mati. Umar bin Khattab berkata pada para amil zakat, "Berikanlah zakat kepada orang (pada masa krisis ini) yang masih memiliki 100 ekor kambing, dan tidak kepada orang yang yang masih memiliki 200 kambing." 26 Dalam fikih syariah, zakat untuk kambing akan ditarik dari pemilik kambing yang memiliki kambing sejumlah 40 ekor. Namun dalam masa krisis ini, Umar memberikan pengecualian dengan tidak menarik zakat pada pemilik 100 ekor kambing. Hal ini karena (pada masa itu) memiliki 100 ekor kambing belum mampu memenuhi kebutuhan dari pemilik kambing tersebut. Bahkan jika kambing-kambing tersebut di jual, akan di jual dengan harga yang sangat tinggi sedangkan pada saat itu para penduduk sudah tidak memiliki harta karena tidak berjalannya aktifitas ekonomi. Pemilik kambing hanya akan menggunakan kambing-kambing tersebut untuk memenuhi kebutuhan sehari-hari untuk menghindari kelaparan, terlebih kekhawatiran karena tidak adanya perkiraan kapan bencana ini akan selesai. Maka kebijakan yang diambil oleh Umar bin Khattab adalah kebijakan yang sangat bijaksana, agar rakyat tidak merasa terzalimi dan bisa merasa aman karena tidak perlu memikirkan lagi tentang pembayaran zakat ternak. Harta pada masa itu juga tidak terlalu banyak membantu karena kurangnya pasokan bahan makanan yang masuk dari Syam yang terjangkit penyakit Pes. Pada masa itu, hanya pemilik 200 ekor kambing yang dianggap mampu memenuhi kebutuhannya sehingga diwajibkan untuk mengeluarkan zakat hingga masa krisis ramadah berakhir.

Kedua, Umar juga berpendapat boleh memajukan pembayaran atau penarikan zakat sebelum datang masa haulnya. Diriwayatkan dari al-Hakam bin Utaibah, ia berkata, "Rasulullah mengutus Umar sebagai petugas zakat. Lalu Umar mendatangi al-Abbas untuk meminta pengeluaran zakat hartanya. Al-Abbas berkata, "Aku telah menyegerakan pengeluaran zakat untuk dua tahun kepada Rasulullah." Lalu Umar melaporkan kasus ini kepada Rasulullah, dan Rasulullah bersabda, “Benar apa yang telah dilakukan oleh pamanku itu. Dia telah mempercepat pengeluaran zakat hartanya kepada kami untuk dua tahun." 27 Atas dasar itu, di masa pemerintahannya, Umar menunda pengambilan zakat hingga datang tahun berikutnya, lalu menghitungnya dengan hitungan dua kali zakat, yaitu zakat yang harus dikeluarkan tahun itu dan zakat yang semestinya dikeluarkan pada tahun sebelumnya. Beberapa riwayat menyebutkan, ketika kondisi telah berubah, hujan telah turun dan tanaman, ternak, begitu juga sumber zakat lainnya sudah berada dalam kondisi yang lebih baik, maka Umar memerintahkan untuk mengambil zakat dari kaum muslimin untuk dua tahun, yaitu tahun di mana zakat itu harus ditunaikan dan tahun sebelumnya yang mana saat itu zakat tidak dipungut. ${ }^{28}$

${ }^{26}$ Al-Haritsi, Jaribah ibn Ahmad. (2015). Fikih Ekonomi Umar bin Khattab. Jakarta: Pustaka al-Kautsar. ${ }^{27} \mathrm{Abu}$ Ubaid al-Qasim, Al-Amwal, (Beirut: Dar Al-Fikr, tt.), h. 702.

${ }^{28}$ Lihat, Al-Husain al-Baghawi, Syarh al-Sunnah, (Cet. VI; Beirut: Al-Maktab Al-Islamy, 1983), h. 35. 


\section{Relevansi Kebijakan Zakat Umar bin Khattab dengan Krisis Pendemi Covid-19}

Berbagai kebijakan ekonomi zakat yang diambil dan dilakukan oleh Umar bin Khattab sesungguhnya memiliki relevansi yang kuat dalam kondisi perzakatan Indonesia, khususnya pada masa krisis pendemi Covid-19 saat ini. Kebijakan-kebijakan tersebut seyogyanya dapat diimplementasi dalam konteks krisis saat ini.

Pertama, kebijakan zakat Umar yang senantiasa memberikan kemudahan dan keluwesan terhadap para muzaki di zamannya, khususnya yang berkaitan dengan objek zakat, seperti disebutkan di dalam bab sebelumnya. Umar bin Khattab secara khusus berpandangan bolehnya mengeluarkan barang sebagai pengganti dari perak dan yang lainnya. Kebijakan ini dilandasi atas prinsip taisir (memberikan kemudahan) bagi para muzaki dan juga melihat kemaslahatan yang dapat dicapai dari sisi mustahik. Pandangan ini juga dikuatkan dengan kebijakan Muadz bin Jabal ketika mengambil zakat dari penduduk Yaman. Muadz memilih mengambil pakaian sebagai pengganti zakat penduduk setempat. Di dalam atsar yang diriwayatkan oleh Imam Bukhari dari Thawus, Muadz berkata, "Berikanlah kepadaku pakaian sebagai pengganti zakat gandum dan jagung, karena itu lebih mudah untuk kalian keluarkan dan lebih bermanfaat bagi kaum muhajirin di Madinah." ${ }^{29}$ Pendapat inilah yang diambil dan dikuatkan oleh banyak ulama kalangan Hanafiyah. ${ }^{30}$ Demikian juga disebutkan dalam sebuah riwayat bahwa Imam Ahmad membolehkan mengeluarkan uang sebagai pengganti zakat pertanian. ${ }^{31}$

Al-Qardhawi berpandangan bahwa pada realitanya, pendapat Hanafiyah lebih sesuai dengan perkembangan zaman sekarang ini dan lebih mudah bagi segenap manusia. Dengan mekanisme seperti ini juga lebih mudah untuk dikalkulasi, khususnya jika terdapat lembaga yang menangani pengumpulan zakat. Karena sesungguhnya mengambil zakat berupa ternak akan mengakibatkan pertambahan cost (biaya), di mana dibutuhkan biaya tambahan untuk transportasi yang di butuhkan guna memindahkan ternak tersebut dari tempat muzaki ke lembaga zakat, berikutnya ke tempat mustahik. Demikian pula halnya dengan biaya pemeliharaan, pakan, kandang dan lain sebagainya. Tentunya hal ini tidak sejalan dengan prinsip efisiensi biaya dalam pengumpulan zakat. ${ }^{32}$

Umar bin Khattab memiliki pandangan analisis yang sangat luar biasa. Misalnya, fakir miskin butuh pakaian, mengapa tidak diberi pakaian. Fakir miskin sekarang misalnya butuh uang, walaupun objek zakatnya padi, ya gak usah dikasi padi, kasi uangkan dong. Sebaliknya, misalnya kita punya zakat uang, tetapi mustahiknya butuh beras, sementara dia kalo mau beli beras, dia sulit, maka boleh saja diganti dengan beras." (Prof. Dr. Didin Hafidhuddin, M.S.) ${ }^{33}$

${ }^{29}$ Shahih al-Bukhari, (Cairo: Dar as-Sya'b, 1987, vol. 2), h. 144.

${ }^{30}$ Yusuf al-Qardhawi, Figh al-Zakah, h. 811.

${ }^{31} \mathrm{Ibnu}$ Qudamah al-Maqdisi, al-Mughni fi Figh al-Imam Ahmad ibn Hanbal al-Syaibani, (Beirut: Dar al-Kutub al-Fikr, 1405, vol. 2), h. 671.

${ }^{32}$ Yusuf al-Qardhawi, Figh al-Zakah, h. 816.

${ }_{33}$ Prof. Dr. Didin Hafidhuddin, M.S., Ketua Umum BAZNAS Periode 2005-2015, Wawancara, Bogor, 12 Agustus 2018. 
Sebagian ulama kontemporer membolehkan untuk memberikan barang yang bermanfaat dan diyakini dibutuhkan oleh mustahik, seperti pakaian, makanan dan lainnya sebagai pengganti zakat harta, emas, perak ataupun uang tabungan. Mufti Kerajaan Saudi Arabia, Syaikh Abdul Aziz bin Baz berpendapat, boleh memberikan barang berupa pakaian atau makanan kepada fakir miskin sebagai pengganti zakat, jika dipandang dengan memberikan barang tersebut terdapat maslahat bagi mustahik, seperti umpamanya yang menerima zakat itu adalah seorang yang kurang waras, safih (tidak bisa mengalokasikan uang pada tempat yang semestinya) atau seorang yang suka membeli sesuatu yang tidak berguna lagi memudharatkan. Demikian itu, diharapkan orang yang menerima zakat tersebut mendapatkan maslahat dari harta zakat yang disalurkan kepadanya. ${ }^{34}$ Oleh karena itu, kebijakan Umar bin Khattab ini memiliki relevansi dengan kondisi dan konteks krisis pandemi saat ini, yaitu seseorang atau pun amil dapat memberikan zakat berupa barang (pakaian atau makanan dan lainnya) kepada seorang mustahik sebagai badal (pengganti) dari zakat harta mereka pada kondisi tertentu, di mana mereka (amil atau muzaki) melihat ada maslahat yang lebih besar yang dapat diraih dengan memberikan badal (pengganti) tersebut. Kebijakan ini juga relevan dengan kebijakan yang diberlakukan oleh beberepa lembaga zakat mengenai pembayaran zakat dengan uang sebagai pengganti hasil tanaman dan peternakan yang sudah mencapai nisab. Demikian ini dilakukan semata-mata untuk mempermudah muzaki dan amil dalam mengumpulkan zakat dan juga karena melihat aspek maslahat, efisiensi biaya dan lain sebagainya.

Kedua, kebijakan Umar bin Khattab dalam penarikan harta zakat yang fleksibel. Ada kalanya Umar mempercepat penarikan zakat, dan pada kondisi lain Umar mengakhirkan penarikan zakat dari muzaki. ${ }^{35}$ Pada konteks penundaan penarikan zakat, Umar bin Khattab mengeluarkan kebijakan untuk tidak memungut zakat dari ternak kaum muslimin di saat terjadi bencana yang melanda Madinah dan sekitarnya, yaitu tahun paceklik yang disebut dengan tahun Ramadah. Akan tetapi pada tahun berikutnya, setelah kondisi wilayah tersebut sudah membaik, Umar bin Khattab memerintahkan untuk menarik zakat dua tahun dari penduduk yang menjadi muzaki di wilayah tersebut, yaitu zakat mereka tahun itu dan zakat tahun sebelumnya yang telah ditunda.

Masalah kebijakan penyegeraan dan penundaan zakat atas dasar kemaslahatan bagi para mustahik seperti yang telah disebutkan di atas, sebenarnya cukup relevan dengan kebijakan pengelolaan perzakatan di Indonesia. Bencana alam yang kerap kali terjadi di negeri ini membutuhkan perhatian yang serius dari berbagai kalangan. Perhatian ini tentunya sangat erat kaitannya dengan bantuan yang bersifat materi, baik berupa makanan pokok, penyediaan obat-obatan dan tenaga medis, begitu juga dengan rekonsiliasi pemukiman penduduk pasca terjadinya bencana, seperti pembangunan rumah-rumah penduduk, pengadaan fasilitas umum dan juga pembangunan prasarana vital umat, seperti masjid, bangunan pendidikan dan lainnya.

${ }^{34}$ Abdul Aziz bin Baz, Majmu' Fatawa al-Syaikh Abdul Aziz ibn Baz, (al-Maktabah al-Syamilah, t.th., vol. 14), h. 253.

${ }^{35} \mathrm{Abu}$ Ubaid al-Qasim, al-Amwal, h. 702. 
Para ulama kontemporer menegaskan bolehnya memajukan pengeluaran zakat jika telah mencapai nisab sekalipun belum genap satu tahun atau datang masa haul. Abdullah al-Syaikh memandang bahwa pendapat yang menyatakan bolehnya memajukan pembayaran zakat lebih kuat dari pendapat yang lain. Demikian itu dengan landasan dalil dari hadis Rasulullah saw, seperti yang disebutkan sebelumnya, dan begitu pula jika ditinjau dari sisi analisis fikihnya. ${ }^{36}$ Pendapat ini diperkuat oleh beberapa fatwa para ulama kontemporer yang menyatakan bolehnya memajukan pembayaran zakat jika ada kondisi darurat yang membutuhkan hal itu.

Umar melakukan hal demikian dengan kapasitasnya sebagai seorang khalifah. Penguasa boleh saja menetapkan aturan dengan kekuasaan. Misalnya mewajibkan sesuatu yang tidak wajib, jika dipandang ada maslahat dalam kebijakan tersebut. Demikian halnya zakat yang disegerakan karena dibutuhkan untuk kepentingan masyarakat kaum fakir. Namun hal ini harus diputuskan oleh seorang pemimpin, buka sekehendak amil.

Salah seorang ulama kontemporer abad ini, Syaikh Ibnu Baz menyatakan bahwa tidak mengapa memajukan zakat sebelum genap satu tahun, jika dipandang di terdapat maslahat syar'i yang dapat dicapai dengan itu. ${ }^{37}$ Adapun Syaikh al-`Utsaimin berpendapat, penyegeraan zakat hanya boleh dilakukan untuk dua tahun, kecuali jika ada kondisi darurat yang membutuhkan penyegeraan zakat dilakukan, seperti kondisi bencana, jihad dan lain sebagainya. ${ }^{38}$ Sementara itu al-Qardhawi menyatakan bolehnya menyegerakan zakat bagi muslimin Palestina yang sedang berada tekanan penjajah Israel. Hal ini, dapat menjadi sebab yang menjadikan zakat harus disegerakan; kerana seorang yang beriman adalah saudara bagi mukmin yang lainnya. ${ }^{39}$ Oleh karena itu, kebijakan Umar bin Khattab ini memiliki relevansi dengan kondisi dan konteks krisis pandemi saat ini, yaitu bahwa pembayaran zakat para muzaki dapat disegerakan sebelum genap setahun dan setelah cukup nisabnya, mengingat adanya kemaslahatan yang besar bagi orang-orang fakir dan miskin yang terdampak wabah pandemi Covid-19 di Indonesia.

\section{KESIMPULAN}

Berdasarkan hasil dan pembahasan, dapat disimpulkan beberapa hal. Pertama, di antara bentuk kebijakan Umar bin Khattab dalam penarikan zakat adalah: (1) Umar bin Khattab membolehkan mengambil badal (pengganti) yang memiliki nilai yang sama dari zakat tersebut sebagai unsur kemudahan (taisir) bagi para muzaki; (2) Umar bin Khattab sangat fleksibel dalam mengambil zakat dari kaum muslimin khususnya pada kondisi dan situasi tertentu, seperti pada krisis. Kedua, berbagai kebijakan Umar bin Khattab tersebut memiliki relevansi yang kuat dengan kondisi krisis pandemi Covid-19 saat ini, sehingga dapat menjadi rujukan untuk menetapkan kebijakan

${ }^{36}$ Abdullah ibn Wakil al-Syaikh, Ta'jil Zakah, www.islamtoday.net. Diakses pada 24/1/2019.

${ }^{37}$ Abdul Aziz ibn Abdullah ibn Baz, Majmu'atu al-Fatawa, (al-Maktabah al-Syamilah, Vol. 14), h. 36.

${ }^{38}$ Muhammad bin Shalih al-'Utsaimin, Majmu' Fatawa wa Rasa'il Ibn 'Utsaimin, (Dar al-Wathan, 1413, vol. 18), h. 213.

${ }^{39}$ Abdullah ibn Wakil al-Syaikh, Ta'jil Zakah. 
perzakatan di Indonesia. Diantaranya: (1) seseorang atau amil dapat memberikan zakat berupa barang (pakaian atau makanan dan lainnya) kepada seorang mustahik sebagai badal (pengganti) dari zakat harta mereka pada kondisi tertentu, di mana mereka (amil atau muzaki) melihat ada maslahat yang lebih besar yang dapat diraih dengan memberikan badal (pengganti) tersebut; (2) pembayaran zakat para muzaki dapat disegerakan sebelum genap setahun dan setelah cukup nisabnya, mengingat adanya kemaslahatan yang besar bagi orang-orang fakir dan miskin yang terdampak wabah pandemi Covid-19 di Indonesia.

\section{REFERENSI:}

Aflaha, A. N. (2019). Manajemen Krisis Ramadah Umar Bin Khattab Perspektif Sejarah Ekonomi Islam. Jurnal Rihlah, Vol. 7, No. 1.

Al-'Utsaimin, Muhammad bin Shalih. (1413). Majmu' Fatawa wa Rasa'il Ibn 'Utsaimin,. Dar al-Wathan, vol. 18, h. 213.

Al-Andalusi, Ali bin Ahmad bin Hazm. (1404). Al-Ihkam fi Usul al-Ahkam. Qahirah: Dar al-Hadis. h. 87.

Al-Baghawi, Al-Husain. (1983). Syarh al-Sunnah. Cet. VI. Beirut: Al-Maktab Al-Islamy. h. 35 .

Al-Haritsi, Jaribah ibn Ahmad. (2015). Fikih Ekonomi Umar bin Khattab. Jakarta: Pustaka al-Kautsar.

Al-Maqdisi, Ibnu Qudamah. (1405). al-Mughni fi Figh al-Imam Ahmad ibn Hanbal al-Syaibani. Beirut: Dar al-Kutub al-Fikr, vol. 2, h. 671.

Al-Qardhawi, Yusuf. (2006). Figh al-Zakah. Cairo: Maktabah Wahbah.

Al-Qasim, Abu Ubaid. (1988). Al-Amwâl. Beirut: Dar Al-Fikr.

Al-Thabari, Ibnu Jarir. (2000) Jami' al-Bayan fi Tafsir Ayi al-Qur'an. Cet. XIV; Beirut: Muassasah Ar-Risalah.

Al-Utsaimin, Muhammad bin Shalih. (1428). Al-Syarhul Mumti' 'Ala Dzad al-Mustaqni', Cet. XIII. Cairo: Dar Ibnul Jauzi, h. 156.

Aqbar, K., \& Iskandar, A. (2019). Kontekstualisasi Ekonomi Zakat dalam Mengentaskan Kemiskinan: Studi Kebijakan Zakat Umar bin Khattab dan Perzakatan di Indonesia. Laa Maisyir: Jurnal Ekonomi Islam, 6(2), 226-245.

Azwar. Solusi Ekonomi dan Keuangan Islam di Masa Pandemi Covid-19. https://www.kemenkeu.go.id/publikasi/artikel-dan-opini/solusi-ekonomi-dankeuangan-islam-saat-pandemi-covid-19/. Diakses pada tanggal 4 Mei 2020.

Baldwin, R., Mauro, B. W. D. (2020). Economics in the Time of Covid-19. New E-Book. The Graduate Institute Geneva (April 2020): p. 1-10.

Haikal, M. H. (1963). Al-Faruq Umar. Qahirah: Maktabah al-Nahdhah al-Mishriyyah, Vol. 1, h. 1. 
Ibnu Abi Syaibah, Abu Bakr. (t.th.). Mushannaf Ibnu Abi Syaibah, Cet. III. Dar as-Salafiyah, h. 181.

Ibnu Baz, Abdul Aziz. (t.th.) (Majmu' Fatawa al-Syaikh Abdul Aziz ibn Baz. Al-Maktabah al-Syamilah, vol. 14 .

Iskandar, A., dan Aqbar, K. (2019). Kedudukan Ilmu Ekonomi Islam di Antara Ilmu Ekonomi dan Fikih Muamalah: Analisis Problematika Epistemologis. Nukhbatul 'Ulum: Jurnal Bidang Kajian Islam, Vol. 5, No. 2 (2019), h. 88-105.

Kasdi, A. (2016). Filantropi Islam Untuk Pemberdayaan Ekonomi Umat (Model Pemberdayaan ZISWAF di BMT Se-Kabupaten Demak). Iqtishadia: Jurnal Kajian Ekonomi dan Bisnis Islam, Vol. 9, No. 2. h. 227-245.

Maniroh, M. (2018). Penyelesaian Krisis Ekonomi menurut Umar bin Khatab"(Analisis terhadap Penundaan Pemungutan Zakat Hewan Ternak). Skripsi: STAIN Tengku Dirundeng Meulaboh.

Marthon, S.S. (2007). Ekonomi Islam di Tengah Krisis Ekonomi Global. Jakarta: Zikrul Hakim. h. 126-128.

Munif, A. (2012). Analisis Pendapat Khalifah Umar Bin Khattab tentang Penundaan Penarikan Zakat Binatang Ternak Kambing yang Telah Mencapai Nisab. Muqtasid: Jurnal Ekonomi dan Perbankan Syariah, 3(2), 205-230.

Pratama, Y.C. (2015). Peran Zakat dalam Penanggulangan Kemiskinan (Studi Kasus: Program Zakat Produktif Pada Badan Amil Zakat Nasional). The Journal of Tauhidinomics, Vol. 1, No. 1 (2015): 93-104.

Qal'ahji, Muhammad Rawwas. (1981). Mausu'ah Figh Umar. Beirut: Dar al-Falah, h. 363. 